\title{
Helseeffekter av sykling til og fra jobb
}

\begin{abstract}
Sammendrag
Bakgrunn. Hensikten med studien var å se om man med enkle midler klarte å motivere til regelmessig sykkelaktivitet til og fra arbeid i ett år, og om dette førte til fysiologiske endringer som kunne gi helsemessig gevinst.
\end{abstract}

Materiale og metode. I studien har man fulgt 25 personer som gjennom ett år har syklet til og fra arbeid. Forsøkspersonenes maksimale oksygenopptak $\left(\mathrm{VO}_{2 \text { maks }}\right)$ og kroppsmasseindeks (BMI) ble målt ved prosjektstart, etter seks måneder og etter ett år. Totalkolesterol og HDL-kolesterol ble målt ved prosjektstart og ved avslutning av prosjektet.

Resultater. $\mathrm{VO}_{2 \text { maks }} \varnothing$ kte i løpet av studien med $15,8 \%$, fra $32,5 \mathrm{ml} / \mathrm{kg} / \mathrm{min}$ (SD 8,1 ) til $37,1 \mathrm{ml} / \mathrm{kg} / \mathrm{min}$ (SD 7,6 ) ( $p<0,001$ ). Det ble funnet en $ø$ kning i HDL-konsentrasjonen på $15,3 \%$, fra $1,31 \mathrm{mmol} / \mathrm{l}$ (SD 0,31) til $1,51 \mathrm{mmol} / \mathrm{l}$ $(S D 0,40)(p<0,001)$ hos deltakerne. Det ble kun registrert små endringer i BMI. Antall sykkeløkter til og fra arbeid ble redusert kraftig i vintermånedene pga. dårlige sykkelforhold.

Fortolkning. Denne studien viser at sykling til og fra jobb kan påvirke fysiologiske variabler som gir helsemessig gevinst.

\author{
Leif Inge Tjelta \\ leif.i.tjelta@uis.no \\ Odd Harald Kvåle \\ Sindre M. Dyrstad \\ Institutt for allmennlærerutdanning \\ og spesialpedagogikk \\ Det humanistiske fakultet \\ Universitetet i Stavanger \\ 4036 Stavanger
}

Å sykle fremfor å kjøre bil gir både helse- og miljømessige gevinster. Hos voksne er det funnet at sykling til og fra arbeid er assosiert med ca. $30 \%$ lavere risiko for tidlig død hos både menn og kvinner etter justering for andre risikofaktorer og generelt aktivitetsnivå $(1,2)$. Epidemiologiske studier har vist at fysisk aktivitet er forebyggende i forhold til utvikling av bl.a. tykktarmskreft, hjerte- og karsykdom, overvekt og diabetes mellitus type 2 (3).

Maksimalt oksygenopptak $\left(\mathrm{VO}_{2 \text { maks }}\right)$ blir oftest klassifisert som den viktigste variabelen når man skal måle personers kondisjon (4). Allerede i 1980-årene påviste man en klar sammenheng mellom lavt oksygenopptak og økt helserisiko (5).

En rekke studier antyder at sedate menn og kvinner har 2-3 ganger større risiko for å utvike hjerte- og karsykdom enn dem som er fysisk aktive i jobb eller i fritiden (6-10). Økt nivå av LDL (low density lipoprotein), VLDL (very low density lipoprotein), IDL (intermediate density lipoprotein) og lipoprotein (a) er knyttet til økt risiko for hjerteog karsykdommer. Økt nivå av HDL (high density lipoprotein) reduserer risikoen (11). Fysisk veltrente personer har normalt høyere nivå av HDL-kolesterol (og lavere innhold av triglyserider) enn utrente personer. Økningen i HDL-kolesterol vurderes som særlig viktig på grunn av dens rolle i prosessen der kroppen trekker ut kolesterol fra perifert vev for å transportere det til leveren og skille det ut (reverse cholesterol transport). HDL-kolesterol $<1,0 \mathrm{mmol} / \mathrm{l}$ hos menn og $<1,1 \mathrm{mmol} / 1$ hos kvinner defineres som risikomarkører (12). En metaanalyse av 25 randomiserte, kontrollerte studier viser at et aktivitetsnivå tilsvarende $900 \mathrm{kcal}$ er det minimumsnivået som skal til for å øke HDLkonsentrasjonen (13).

Overvekt og fedme blir gjerne definert på grunnlag av kroppsmasseindeks (BMI) (14). Inaktive personer er i større grad overvektige enn de fysisk aktive (15-17). Stor grad av overvekt og fedme innebærer en rekke ulike risikoer: høyt blodtrykk (hypertoni), blodfettforstyrrelser (dyslipidemi) og diabetes, som samlet utgjør det metabolske syndromet (18-20).

Kartleggingen av den norske befolknings aktivitetsvaner i 2008 og 2009 viser at kun $20 \%$ tilfredsstiller Helsedirektoratets anbefalinger for fysisk aktivitet (17). I en annen stor norsk undersøkelse gjennomført i 2007 fremkom det at $76 \%$ av dem som ble definert som fysisk inaktive ønsket å komme i gang med regelmessig fysisk aktivitet (21). Dette peker på viktigheten av aktivitetsstimulerende tiltak som kan hjelpe motiverte mennesker til å bli mer fysisk aktive.

«På egen sykkel» (PES) var et samarbeidsprosjekt mellom Statens vegvesen, Stavanger kommune og Universitetet i Stavanger. Hensikten var å se om regelmessig sykkelaktivitet $\mathrm{i}$ ett år førte til fysiologiske endringer som kunne gi helsemessig gevinst.

Det er få småskalaintervensjoner som blir publisert, og vi har ikke funnet noen studier der man har evaluert sykle-til-jobben-aksjoner. Resultatene fra denne studien vil derfor kunne være av interesse for andre som ønsker å gjennomføre liknende tiltak.

\section{Materiale og metode}

Det ble annonsert etter prosjektdeltakere i lokalpressen. Deltakerne ville få ny sykkel og hjelm, og skulle så langt som mulig sykle til og fra jobb i 12 måneder. Inklusjonskriteriene var at deltakeren skulle:

- ha minimum $5 \mathrm{~km}$ avstand fra hjem til arbeid

- ha bostedsadresse i Stavanger kommune - vanligvis ha kjørt bil til og fra arbeid

\section{Hovedbudskap}

- Småskalatiltak som sykle-til-jobbenprosjekt kan gi god effekt på ulike fysiologiske parametre som har helsemessig relevans

- Denne type intervensjon kan igangsettes av bl.a. arbeidsgivere for å stimulere helsefremmende atferd blant ansatte

- For å øke effekten anbefales det å legge opp alternative bevegelsesaktiviteter gjennom vintermånedene 
- ha et arbeid som krevde lite fysisk aktivitet

- ikke drive med regelmessig fysisk aktivitet $\mathrm{i}$ fritiden

Ved utvelgelsen ble det lagt vekt på å få aldersspredning i gruppen og at begge kjønn var representert. To lokale sponsorbedrifter fikk inkludert fem prosjektdeltakere hver ut fra nevnte inklusjonskriterier. Loddtrekning ble foretatt dersom personer var likt kvalifisert til å delta i prosjektet. Ut ifra de økonomiske rammene var det ønskelig å ha ca. 25 personer med i prosjektet. For å ta høyde for noe frafall ble totalt 29 personer inkludert (fig 1). Skriftlig informert samtykke fra deltakerne ble innhentet, og de kunne når som helst trekke seg fra prosjektet uten at dette fikk noen konsekvenser.

Deltakerne møtte på seks kveldssamlinger i løpet av prosjektperioden. Samlingene hadde ulike temaer, som trafikk- og sykkelkultur, stell og vedlikehold av sykkel og helsegevinster knyttet til fysisk aktivitet. Ved prosjektstart ble deltakerne instruert i utfylling av treningsdagbøkene. Det var et enkelt standardisert skjema som inkluderte antall kilometer og tid de syklet per dag. Annen aktivitet som turgåing ble også notert. Treningsrapportene ble sendt på e-post til en av prosjektlederne en gang i måneden gjennom 12 måneder. Etter intervensjonsperioden svarte alle deltakerne på et spørreskjema som omhandlet motivasjon og erfaringer fra prosjektet.

Til måling av $\mathrm{VO}_{2 \text { maks }}$ ble Vmax 29 (SensorMedics, Yorba Linda, CA, USA) benyttet. Gassanalysatoren ble kalibrert før hver testdag og etter hver fjerde $\mathrm{VO}_{2 \text { maks }}$-test. Vmax 29-sensor er en gassanalysator som kalibrert mot Douglas bag-metode og andre gassanalysatorer har vist stor grad av validitet og reliabilitet (22). Lufttemperaturen i laboratoriet var $18-20{ }^{\circ} \mathrm{C}$, og relativ luftfuktighet var $40-50 \%$. Tredemølle av merket Woodway, Ergo ELG 55 (Weil am Rhein, Tyskland) ble benyttet som ergometer. Stigningsvinkelen på tredemøllen var 5,2\%. Deltakernes hjertefrekvens ble registrert hvert femte sekund ved hjelp av Polar Sports Tester (Polar Electro Oy, Kempele, Finland). De ble bedt om å unngå røyking og snusing de siste fire timene før testen samt mat de siste to timene.

Før teststart ble høyde og kroppsvekt målt. Deltakerne varmet opp i 15 minutter (sykling eller gang og jogg) og fikk deretter grundig tilvenning til tredemøllen. Antrekk var lett treningstøy og joggesko. Testen startet med gange eller rolig jogg på en hastighet der hjertefrekvensen var 110-140 slag/min. Tredemøllehastigheten ble økt med $0,5 \mathrm{~km} / \mathrm{t}$ hvert 30 . sekund til man nådde den høyeste hastighet som deltakeren mente han/hun var i stand til å holde ut i minimum ett minutt. Testen varte 4-7 minutter.

Frivillig utmattelse, dvs. at deltakerne hoppet av tredemøllen når de ikke klarte å fortsette, var hovedkriterium på at $\mathrm{VO}_{2 \text { maks }}$ var nådd, og høyeste gjennomsnittlige $\mathrm{VO}_{2}$ over ett minutt ble satt som $\mathrm{VO}_{2 \text { maks }}$. Hvis det var tvil om at forsøkspersonen var utmattet, ble følgende hjelpekriterier brukt for å bekrefte utmattelse:

- utflating av $\mathrm{VO}_{2}$-kurven ved økende belastning

- R-verdi $>1,00$ (R-verdi $=$ respiratorisk utvekslingskvotient, forholdet mellom volumet av produsert karbondioksid og forbrukt volum av oksygen)

Ved prosjektstart og etter 12 måneder ble totalkolesterol og HDL-kolesterol målt fastende om morgenen av medisinsk personell ved et legesenter.

Resultatene er presentert som gjennomsnittsverdier med standardavvik (SD). T-test ble brukt for å sammenlikne to gjennomsnittsverdier for en gitt variabel. Forskjeller ble sett på som statistisk signifikante dersom p-verdien var mindre enn 0,05 . For å studere sammenhengen mellom tid brukt på fysisk aktivitet og endringer i $\mathrm{VO}_{2 \text { maks }}$ ble Pearsons korrelasjonskoeffisient (r) benyttet.

\section{Resultater}

Totalt 149 personer (112 menn og 37 kvinner) søkte om å få delta i prosjektet (fig 1). I starten ble 29 personer valgt ut til å delta $\mathrm{i}$ prosjektet. En mannlig forsøksperson droppet ut etter en måned. En kvinne ble ekskludert pga. problemer med selve testsituasjonen, mens to ble ekskludert pga. graviditet. Totalt 25 personer (19 menn og 6 kvinner) gjennomførte prosjektet. Kjønn og alder er beskrevet i tabell 1 .

Endringene i BMI gjennom teståret er vist i tabell 2. Totalt åtte personer hadde en BMI over 30 ved forsøksstart. Etter seks måneder var BMI for disse redusert med 4,0\%, fra
Tabell 1 Forsøkspersonenes gjennomsnittsalder med standardavvik (SD) ved prosjektstart

\begin{tabular}{lccc} 
& $N$ & Alder (år) & SD \\
\hline Alle & 25 & 42,6 & $(7,5)$ \\
\hline Menn & 19 & 43,0 & $(8,4)$ \\
\hline Kvinner & 6 & 41,5 & $(4,1)$
\end{tabular}

$32,9(3,3)$ til $31,6(3,5)(p=0,001)$. BMI økte deretter de neste seks månedene til $32,4(3,3)$, slik at det etter ett år ikke var endringer i denne variabelen fra prosjektstart til -slutt.

Gjennomsnittlig $\mathrm{VO}_{2 \text { maks }}$ økte hos alle de første seks månedene, for så å avta de neste seks. Fremgangen gjennom året som helhet er likevel signifikant (tab 3). En deltaker, som ved prosjektstart hadde $\mathrm{VO}_{2 \text { maks }}$ på 19,6 $\mathrm{ml} / \mathrm{kg} / \mathrm{min}$, syklet daglig $25-27 \mathrm{~km}$ og hevet $\mathrm{VO}_{2 \text { maks }}$ til $36,2 \mathrm{ml} / \mathrm{kg} / \mathrm{min}$ - en økning på hele $87 \%$. To andre menn, med et utgangspunkt på $42,4 \mathrm{ml} / \mathrm{kg} / \mathrm{min}$ og $52 \mathrm{ml} / \mathrm{kg} / \mathrm{min}$, hevet $\mathrm{VO}_{2 \text { maks }}$ henholdsvis $36 \%$ og $10 \%$ ved å sykle $32 \mathrm{~km}$ og $40 \mathrm{~km}$ per dag. Størst fremgang blant kvinnene hadde deltakeren som syklet $16-32 \mathrm{~km}$ per dag. Fremgangen var fra $29,4 \mathrm{ml} / \mathrm{kg} / \mathrm{min}$ til $42,6 \mathrm{ml} / \mathrm{kg} / \mathrm{min}$ $(45 \%)$.

Hos menn, men ikke hos kvinner, ble det funnet en nedgang i totalkolesterol gjennom prosjektperioden (tab 3). Det ble imidlertid funnet en økning i HDL hos både kvinner og menn (tab 3). Gjennomsnittlig treningstid per måned er vist $i$ tabell 4 . Her ser man også at aktiviteten sommer og høst (mai t.o.m. oktober) er $30 \%$ høyere enn aktiviteten vinter og vår (november t.o.m. april). Det ble funnet en signifikant korrelasjon mellom

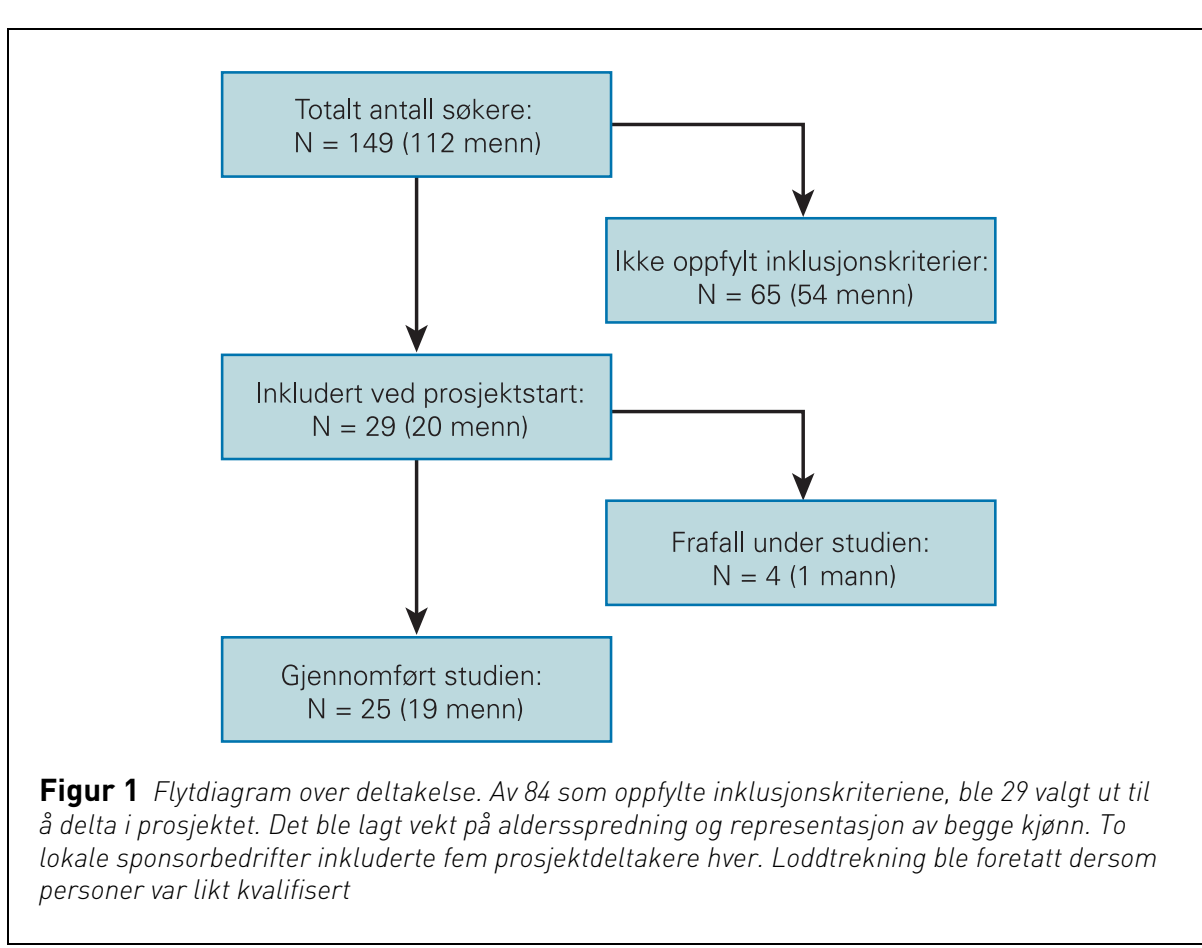


Tabell 2 Endringer i kroppsmasseindeks (BMI) gjennom teståret. Gjennomsnitt (standardavvik) BMI

\begin{tabular}{lrccc} 
& $N$ & Ved start & Etter seks måneder & Etter ett år \\
Alle & 25 & $27,5(4,7)$ & $26,7(4,3)^{1}$ & $27,1(4,6)^{2}$ \\
\hline Kvinner & 6 & $25,8(6,3)$ & $25,7(5,9)$ & $26,1(5,8)$ \\
\hline Menn & 19 & $28,0(4,2)$ & $27,0(3,9)^{1}$ & $27,5(4,3)^{3}$
\end{tabular}

Forskjellig fra start $(p<0,001)$

${ }^{2}$ Forskjellig fra start $(p=0,004)$ og fra seks måneder $(p=0,007)$

${ }^{3}$ Forskjellig fra start ( $\left.p=0,02\right)$ og fra seks måneder $(p=0,002)$

gjennomsnittlig antall minutter fysisk aktivitet per måned og endring $\mathrm{i} \mathrm{VO}_{2 \text { maks }}$ gjennom et år $(\mathrm{r}=0,45, \mathrm{p}<0,05, \mathrm{n}=23)$.

På spørsmålet om den viktigste årsaken til å bli med i prosjektet, svarte $68 \%$ bedret helse, $13 \%$ oppfølging med testing, $9 \%$ gratis sykkel, $5 \%$ endring i bilbruk og $5 \%$ utfordring $(\mathrm{n}=25)$. Til påstanden «Jeg kommer til å bruke sykkelen daglig i fremtiden», svarte $4 \%$ at de var helt eller delvis uenig, $25 \%$ var verken enig eller uenig, mens $71 \%$ var helt eller delvis enig $(n=25)$.

\section{Diskusjon}

Intervensjonen med oppfølging og gratis sykkel for å øke sykkelbruken til og fra arbeid førte til en endring i aktivitetsnivået og økning av $\mathrm{VO}_{2 \text { maks }}$ hos samtlige prosjektdeltakere. Økningen i $\mathrm{VO}_{2 \text { maks }}$ var størst hos dem som syklet lengst og hyppigst, og det var stor variasjon i aktivitetsmengden gjennom årstidene. Deltakelsen førte ikke til endring i BMI, men vi så en tendens til at BMI fulgte svingningene i aktivitetsnivået. Totalkolesterol og HDL ble signifikant gunstigere etter ett år med sykling til og fra arbeid.

Dårlig kondisjon er en risikofaktor for tidlig død. Den markant økte risikoen som lav kondisjon innebærer, begynner ved $\mathrm{VO}_{2 \text { maks }}$ like under $30 \mathrm{ml} / \mathrm{kg} / \mathrm{min}$ (23), som var utgangsverdien for kvinnene i denne studien. De fleste utrente personer kan ved hjelp av trening øke sitt maksimale oksygenopptak med $20-30 \%$, muligens mer (24). I denne studien økte $\mathrm{VO}_{2 \text { maks }}$ med $22 \%$ etter seks måneder, for så å gå noe tilbake. Årsaken kan være at for de første seks månedene, som er sommer og høst, rapporterte deltakerne tilnærmet daglig sykling til og fra arbeid. Etter seks måneder var den relative fremgangen størst hos de deltakerne som i utgangspunktet hadde et lavt oksygenopptak og som syklet flest antall kilometer per uke. Man ser også betydelig fremgang hos de deltakerne med høyere $\mathrm{VO}_{2 \text { maks }}$ som syklet jevnlig. I desember, januar og februar var tiden brukt til fysisk aktivitet $65 \%$ lavere enn i sommer- og høstmånedene. Flere av deltakerne rapporterte at de ofte lot sykkelen stå grunnet glatte veier og vanskelige kjøreforhold (snø, is og mørke). For mange ble syklingen betydelig mindre regelmessig i denne perioden enn den var i startfasen. Tilbakegangen var størst hos dem som rapporterte flere og lengre perioder med få og ingen sykkeløkter per uke. Det var altså kun de mest motiverte som brukte sykkelen til og fra arbeid gjennom vintermånedene.

Kartleggingen av den norske befolknings aktivitetsvaner i 2008 og 2009 viser at det gjennomsnittlige fysiske aktivitetsnivået var rundt $10 \%$ lavere om vinteren sammenliknet med høsten (17). At det er en langt større reduksjon i den fysiske aktiviteten i denne studien, tyder på at sykling kan være mer væravhengig enn andre aktiviteter. Skulle man ha redusert tilbakegangen i $\mathrm{VO}_{2 \text { maks }}$ hos de litt mindre motiverte, kunne man ha tilbudt eller motivert til alternative bevegelsesaktiviteter i vintermånedene. Man kunne også ha hatt en tettere oppfølging gjennom vinteren og motivert for vintersykling bl.a. ved å gi nyttige sykkeltips.

Når BMI overstiger 30 (fedme klasse 1), øker risikoen for å pådra seg hjerte- og karsykdom og høyt blodtrykk (14). Det var ingen større endringer i BMI for gruppen som helhet fra første til siste test, men alle åtte personene med BMI over 30 reduserte denne etter seks måneder. Etter 12 måneder had- de sju av åtte personer økt BMI sammenliknet med seksmånederstesten. Dette er også en tendens hos resten av forsøkspersonene og er trolig en av årsakene til at $\mathrm{VO}_{2 \text { maks }}$ har sunket i samme tidsrom. Oppgangen i BMI kan ha sammenheng med betydelig færre rapporterte ukentlige sykkeløkter.

Noen personer har imidlertid hatt reduksjon i BMI fra andre til tredje test. Disse har også hatt en positiv utvikling av $\mathrm{VO}_{2 \text { maks }} \mathrm{i}$ samme tidsrom. Deres treningsdagbøker viser at treningshyppigheten ikke ble redusert gjennom vintermånedene. Endringene i BMI er relativt små etter et år med sykling til og fra arbeid. Dette samsvarer med andre studier, der man konkluderer med at å øke mengden kondisjonstrening uten samtidig å utføre endringer i diett kun fører til en liten vektreduksjon hos så vel kvinner som menn $(25,26)$. Overvektige personer trenger imidlertid ikke å gå ned i vekt for at trening skal ha helsefremmende effekt $(27,28)$. Moderat aktivitet er assosiert med signifikant lavere risiko for tidlig død (27-29), og fysisk aktivitet vil kunne være med på å bedre ratioen mellom muskler og fett uten at kroppsvekten går ned.

I denne studien har man ikke fokusert på å endre kostholdet til forsøkspersonene. Det er derfor nærliggende å anta at endringene i kolesterol primært er forårsaket av økt mengde aktivitet, selv om forsøkspersonene kan ha endret kostholdsvaner som følge av deltakelse i prosjektet. Økningen i HDL-kolesterol hos deltakerne i denne studien var på $15,3 \%$. Den er større enn det man fant $i$ en norsk studie, der statinbehandlede pasienter med høy risiko for aterosklerotisk sykdom hadde $10 \%$ økning i HDL-kolesterol (30). Fysisk aktivitet er også den eneste kjente metoden for å øke HDL-kolesterolet som ikke er forbundet med bivirkninger (11).

Flere studier peker på at bedre utholdenhet $(5,31,32)$ og økt nivå av HDL-kolesterol $(13,33)$ har helsefremmende effekt. Derfor kan vi anta at personene i denne studien etter ett år med sykling til og fra arbeid har redusert sannsynligheten for å få pådra seg sykdommer som er assosiert med en inaktiv livsstil. Bedre helse var for de fleste av deltakerne også den viktigste grunnen til å delta i prosjektet. Siden mange svarte at de vil bruke sykkelen daglig i fremtiden, kan slike lokale tiltak være viktig for å stimulere til mer aktiv livsstil.

Tabell 3 Maksimalt oksygenopptak $\left(\mathrm{VO}_{2 \text { maks }}\right)$ ved prosjektstart, etter seks måneder og etter ett år samt totalkolesterol (TK) og HDL-kolesterol ved prosjektstart og etter ett år. Gjennomsnitt (standardavvik)

\begin{tabular}{|c|c|c|c|c|c|c|c|c|c|c|}
\hline & \multicolumn{4}{|c|}{$\mathrm{VO}_{2 \text { maks }}(\mathrm{ml} / \mathrm{kg} / \mathrm{min})$} & \multicolumn{3}{|c|}{ TK (mmol/l) } & \multicolumn{3}{|c|}{$\mathrm{HDL}(\mathrm{mmol} / \mathrm{l})$} \\
\hline & $N$ & Ved start & Etter seks md & Etter ett år & $N$ & Ved start & Etter ett år & $\mathrm{N}$ & Ved start & Etter ett år \\
\hline Alle & 25 & $32,5(8,3)$ & $39,9(8,0)^{1}$ & $37,1(7,7)^{1}$ & 23 & $5,57(1,46)$ & $5,22(1,32)^{2}$ & 23 & $1,31(0,31)$ & $1,51(0,40)^{1}$ \\
\hline Menn & 19 & $33,8(8,7)$ & $41,4(7,8)^{1}$ & $38,9(8,0)^{2}$ & 18 & $5,88(0,15)$ & $5,35(0,14)^{3}$ & 18 & $1,28(0,33)$ & $1,46(0,42)^{4}$ \\
\hline Kvinner & 6 & $28,1(4,8)$ & $35,0(7,0)^{3}$ & $31,5(2,7)^{5}$ & 5 & $4,44(0,20)$ & $4,46(0,22)$ & 5 & $1,42(0,22)$ & $1,72(0,23)^{6}$ \\
\hline
\end{tabular}

${ }^{1}$ Forskjellig fra start $(p<0,001) \mid{ }^{2}$ Forskjellig fra start $(p=0,005) \mid{ }^{3}$ Forskjellig fra start $(p=0,002)$

${ }^{4}$ Tenderer til forskjellig i forhold til startverdi $(p=0,051) \mid{ }^{5}$ Forskjellig fra start $(p=0,004) \mid{ }^{6}$ Forskjellig fra start $(p=0,003)$ 
Tabell 4 Rapportert tid i minutter per måned som er brukt til fysisk aktivitet. Dette er i hovedsak sykkelaktivitet, men fotturer er også inkludert

Minutter treningstid per md

\begin{tabular}{llc} 
Periode & N & $\begin{array}{r}\text { Gjennomsnitt } \\
\text { (standardavvik }\end{array}$ \\
\hline Mai & 22 & $884(422)$ \\
\hline Juni & 20 & $922(611)$ \\
\hline Juli & 21 & $801(420)$ \\
\hline August & 21 & $953(534)$ \\
\hline Sept. & 22 & $989(508)$ \\
\hline Okt. & 19 & $960(840)$ \\
\hline Nov. & 16 & $745(297)$ \\
\hline Des. & 16 & $561(351)$ \\
\hline Jan. & 14 & $555(296)$ \\
\hline Feb. & 13 & $392(336)$ \\
\hline Mars & 15 & $583(386)$ \\
\hline April & 11 & $711(404)$ \\
\hline Mai-okt. & 17 & $831(341)$ \\
\hline Nov.-april & 17 & $5831(288)$ \\
\hline IForsketg fra & & $0,001)$
\end{tabular}

${ }^{1}$ Forskjellig fra mai-oktober $(p<0,001)$

\section{Begrensninger ved studien}

Det er en relativt liten gruppe som deltar i studien, og de er sin egen kontrollgruppe. Man må derfor være forsiktig med hvilke konklusjoner som trekkes. Selv om intervensjonen i denne studien er økt sykkelaktivitet til og fra arbeid, kan endringene i $\mathrm{VO}_{2 \text { maks }}$ og HDL-kolesterol også være påvirket av andre faktorer. Deltakerne kan ha blitt motivert til å være mer aktive generelt, slik at endringene ikke kun skyldes sykling. De kan også ha blitt påvirket til å spise sunnere og å stumpe røyken. Hovedbudskapet fra denne studien er derfor ikke at det nødvendigvis er kun sykling til og fra arbeid som har medført de positive endringene, men at en slik intervensjon motiverer til økt fysisk aktivitet og dermed flere helsemessige gevinster.

Oppgitte interessekonflikter: Ingen

\section{Litteratur}

1. Matthews CE, Jurj AL, Shu XO et al. Influence of exercise, walking, cycling, and overall nonexercise physical activity on mortality in Chinese women. Am J Epidemiol 2007; 165: 1343-50.

2. Andersen LB, Schnohr P, Schroll M et al. Allcause mortality associated with physical activity during leisure time, work, sports, and cycling to work. Arch Intern Med 2000; 160: 1621-8.

3. Andersen SA, Strømme SB. Fysisk aktivitet og helse - anbefalinger. Tidsskr Nor Lægeforen 2001 17: 2037-41.

4. Fletcher GF, Balady G, Blair SN et al. Statement on exercise: Benefits and recommendations for physical activity programs for all Americans - A statement for health professionals by the committee on exercise and cardiac rehabilitation of the council on clinical cardiology, American Heart Association. Circulation 1996: 94: 857-62.

5. Blair SN, Kohl HW 3rd, Paffenbarger RS jr. et al. Physical fitness and all-cause mortality. A prospective study of healthy men and women. JAMA 1989; 262: 2395-401

6. Manson JE, Hu FB, Rich-Edwards JW et al. A prospective study of walking as compared with vigorous exercise in the prevention of coronary heart disease in women. N Engl J Med 1999; 341 : $650-8$.

7. Chandrashekhar Y, Anand IS. Exercise as a coronary protective factor. Am Heart J 1991; 122: 1723-39.

8. Smith SC, Blair SN, Criqui MH et al. Preventing heart-attack and death in patients with coronary disease. Circulation 1995; 92: 2-4.

9. Sandvik L, Erikssen J, Thaulow E et al. Physical fitness as a predictor of mortality among healthy. middle-aged Norwegian men. N Engl J Med 1993; 328: $533-7$

10. Yusuf S, Hawken S, Ounpuu S et al. Effect of potentially modifiable risk factors associated with myocardial infarction in 52 countries (the INTERHEART study): case-control study. Lancet 2004; 364 : 937-52.

11. Björck L, Thelle DS. Lipider. I: Bahr R, red. Aktivitetshåndboken. Fysisk aktivitet i forebygging og behandling. Oslo: Helsedirektoratet, 2008: 387-94.

12. Wood D, De Backer G, Faergeman 0 et al. Prevention of coronary heart disease in clinical practice: Recommendations of the Second Joint Task Force of European and other Societies on Coronary Prevention. Atherosclerosis 1998: 140: 199-270.

13. Kodama S, Tanaka S, Saito K et al. Effect of aerobic exercise training on serum levels of high-density lipoprotein cholesterol - a meta-analysis. Arch Intern Med 2007: 167: 999-1008.

14. Obesity: Preventing and managing the global epidemic. Report of a WHO consultation. Technical Report Series nr. 894. Genève: WHO, 2000.

15. Mustelin L, Silventoinen K, Pietilainen $\mathrm{K}$ et al. Physical activity reduces the influence of genetic effects on BMI and waist circumference: a study in young adult twins. Int J Obes 2009; 33: 29-36.

16. Ferrari CK. Metabolic syndrome and obesity: Epidemiology and prevention by physical activity and exercise. J Exerc Sci Fit 2008; 6: 87-96.

17. Andersen SA, Bjørge HH, Kolle E et al. Fysisk akti vitet blant voksne og eldre i Norge. Resultater fra en kartlegging i 2008 og 2009. Oslo: Helsedirektoratet, 2009.
18. Després JP. Lemieux I. Abdominal obesity and metabolic syndrome. Nature 2006; 444: 881-7.

19. Defay R, Delcourt C, Ranvier M et al. Relationships between physical activity, obesity and diabetes mellitus in a French elderly population: the POLA study. Int J Obes 2001; 25: 512-8.

20. Hu G, Lindstrom J, Valle TT et al. Physical activity, body risk of type 2 diabetes in patients with norma or impaired glucose regulation. Arch Intern Med 2004; 164: 892-6.

21. Ommundsen Y, Aadland A. Fysisk inaktive i Norge. Hvem er inaktive - og hva motiverer til økt fysisk aktivitet? Oslo: Helsedirektoratet, Den norske kreftforening, Norges Bedriftsidrettsforbund, 2009

22. Macfarlane DJ. Automated metabolic gas analysis systems: a review. Sports Med 2001; 31: 841-61.

23. Saltin B. Fysisk inaktivitet - en glemt risikofaktor. Perspektiv 2001; nr. 2: 10-5

24. Saltin B. The physiological and biochemical basis of aerobic and anaerobic capacities in man; Effect of training and range of adaption. I: Mæhlum S, Nilson S, Renström P, red. An update on sport medicine. Oslo: Norwegian Sports Medicine Association, 1987.

25. Ballor DL, Keesey RE. A metaanalysis of the factors affecting exercise-induced changes in body mass, fat and fat-free mass in males and females. Int J Obes 1991; 15: 717-26.

26. Garrow JS, Summerbell CD. Metaanalyses - effect of exercise, with or without dieting, on the bodycomposition of overweight subjects. Eur J Clin Nutr 1995; 49: 1-10.

27. Church TS, Cheng YJ, Earnest CP et al. Exercise capacity and body composition as predictors of mortality among men with diabetes. Diabetes Care 2004; 27: 83-8.

28. Wessel TR, Arant CB, Olson MB et al. Relationship of physical fitness vs body mass index with coronary artery disease and cardiovascular events in women. JAMA 2004; 292: 1179-87.

29. Haennel RG, Lemire F. Physical activity to prevent cardiovascular disease - how much is enough? Can Fam Physician 2002; 48: 65-71.

30. Svilaas A, Risberg K, Thoresen M et al. Lipid treatment goals achieved in patients treated with statin drugs in Norwegian general practice. Am J Cardiol 2000; 86: 1250-3

31. Williams PT. Relationship of distance run per week to coronary heart disease risk factors in 8283 male runners - The national runners' health study. Arch Intern Med 1997; 157: 191-8.

32. Wei M, Gibbons LW, Kampert JB et al. Low cardiorespiratory fitness and physical inactivity as predictors of mortality in men with type 2 diabetes. Ann Intern Med 2000; 132: 605-11.

33. Grundy SM. Metabolic syndrome: Connecting and reconciling cardiovascular and diabetes worlds. J Am Coll Cardiol 2006; 47: 1093-100.

Manuskriptet ble mottatt 23.6. 2009 og godkjent 19.3. 2010. Medisinsk redaktør Åslaug Helland. 